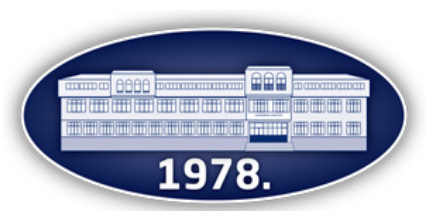

\title{
The response of garden pea cultivars to simulated drought
}

\author{
Gordana Tamindžić*, Janko Červenski, Dragana Milošević, Slobodan Vlajić, \\ Zorica Nikolić, Maja Ignjatov
}

Institute of Field and Vegetable Crops, National Institute of the Republic of Serbia, Maksima Gorkog 30, 21000 Novi Sad, Serbia

*Corresponding author: gordana.tamindzic@ifvcns.ns.ac.rs

Received 7 April 2021; Accepted 15 November 2021

\begin{abstract}
A B S T R A C T
This study aimed to estimate genetic variability among four pea cultivars and determine seed physiological quality and initial growth of garden pea (Pisum sativum L.) under drought stress. Seeds of the pea cultivars were subjected to water stress induced by polyethylene glycol PEG 6000 at three stress levels $(0 ;-0.15 ;-0.49$, and $-1.03 \mathrm{MPa})$. The experiment was conducted under laboratory conditions, in a completely randomized design with four replications, to estimate germination energy, germination, abnormal seedlings, fresh and dry shoot and root biomass, and drought tolerance index. Drought stress significantly affected germination and the other traits, with the stress effects being proportional to the stress level applied. Findings point to the fact that the osmotic potential of $-0.49 \mathrm{MPa}$ might be the germination sensitivity threshold for pea cultivars. The pea cultivar C1 was the most tolerant, having the highest germination, fresh and dry shoot and root biomass, and DTI under severe drought stress. Further research on the assessment of physiological and biochemical responses to drought stress is needed to confirm the findings of the present study.
\end{abstract}

Keywords: drought, Pisum sativum L., seed germination, seedling growth, drought tolerance

\section{И 3 В О Д}

Циљ ове студије био је да процени генетску варијабилност четири сорте грашка и утврди физиолошки квалитет семена и почетни раст повртарског грашка (Pisum sativum L.) у условима стреса суше. Семе сорти грашка подвргнуто је дефициту воде изазваном полиетилен-гликолом 6000 на три нивоа стреса $(0 ;-0,15 ;-0,49$ и -1,03 МРа). Експеримент је изведен у лабораторијским условима, у потпуно случајном дизајну са четири понављања. Процењена је енергија клијања, клијавост семена, атипични изданци, свежа и сува биомаса надземног дела изданака и корена и индекс толеранције на сушу. Стрес суше значајно је утицао на клијавост и друге особине, а ефекти стреса су били пропорционални изазваном нивоу стреса. Резултати указују на чињеницу да би осмотски потенцијал од -0,49 МРа могао бити праг осетљивости на клијавост сорти грашка. Сорта грашка Ц1 показала се као најтолерантнија, имала је највећу клијавост, свежу и суву биомасу корена и изданака и индекс толерантности под јаким стресом суше. Даља истраживања на тему процене физиолошких и биохемијских одговора на стрес суше потребна су да би се потврдили налази ове студије.

Кључне речи: суша, Pisum sativum L., клијавост семена, раст изданака, отпорност на сушу

\section{Introduction}

Worldwide agricultural productivity is exposed to increasing environmental constraints in the form of abiotic stresses, which affect plant growth and development, causing yield loss of more than $50 \%$ (Wu et al., 2011; Vijay et al., 2018). Drought stress is considered a major factor limiting crop production. It has been estimated that more than $60-70 \%$ of the total arable land is affected by drought (Radić et al., 2018).

Reduced water availability in the soil is the main component of drought stress (Mohammadkhari and Heidri, 2008), leading to an increase in the concentration of dissolved substances, acceleration of degenerative reactions, denaturation of proteins, loss of membrane integrity and a significant increase in abnormal seedlings (Pereira et al., 2020). Reduced water availability affects germination, initial growth, root development and shoot elongation, which is a critical phase in seedling establishment. Water deficit leads to a reduction in germination or even its absence (Miladinov et al., 2020).

Laboratory studies often use aqueous solutions with different osmotic potentials to regulate moisture in the germination substrate and simulate water in the soil (Pereira et al., 2020). Polyethylene glycol (PEG) 6000 is a metabolically inactive compound commonly used to simulate water stress conditions by inducing osmotic potential in vitro. It is a non-ionic polymer of high molecular weight range, which cannot penetrate plant cells, thus preventing toxic effects (Channaoui et al., 2019). Polyethylene glycol is the best solute for 
imposing low water potential (Versules and Bray, 2004).

Pea (Pisum sativum L.) is an important legume in vegetable production, which, together with other legumes, provides one-third of the entire amount of protein for human consumption (Petrović et al., 2016). In Serbia, garden pea is grown on 13,000 hectares annually (Jovićević, 2011). Mainly grown under rainfed conditions, pea is often exposed to drought stress during germination and initial growth, which significantly affects its production.

Deleterious effects of PEG-induced drought stress in many crops, for example maize (Mohammadkhari and Heidri, 2008; Radić et al., 2018), wheat (Rana et al., 2017), and Lathyrus species (Piwowarczyk et al., 2014), can be found in the available literature. Previous studies on legumes examined the effects of drought stress on the seed quality of large legumes, such as soybean (Vijay et al., 2018; Basal et al., 2020), while few studies have been conducted on pea cultivars (Fougereux et al., 1997; Pereira et al., 2020). Furthermore, the studies revealed genotypic differences between hybrids and cultivars in terms of drought tolerance. In this regard, the drought tolerance index in many crops was shown to be an appropriate indicator of drought tolerance (Badr et al., 2020).

However, information on the effects of drought on the physiological seed quality of Serbian pea varieties is scarce. Therefore, the aim of the study was to assess the physiological quality of pea seeds in response to drought stress under controlled conditions, and identify the most drought tolerant pea varieties.

\section{Materials and methods}

The experiment was conducted in the Laboratory for Seed Testing of the Institute of Field and Vegetable Crops, the National Institute of the Republic of Serbia, Novi Sad, Serbia. The plant material consisted of four pea cultivars ( $\mathrm{C} 1, \mathrm{C} 2, \mathrm{C} 3$, and $\mathrm{C} 4)$. The tested cultivars were obtained from the Institute of Field and Vegetable Crops, the National Institute of the Republic of Serbia, Novi Sad, Serbia. The seeds were taken randomly from the seed lots obtained in the same year at the location Rimski Šančevi, Novi Sad.

The seeds of the tested pea cultivars were submitted to a germination test, using different osmotic potentials $(-0.15,-0.49$, and $-1.03 \mathrm{MPa})$ of polyethylene glycol (PEG) 6000 solutions to simulate drought (Nicholas, 1989). The PEG 6000 solutions were prepared according to the specification in Table 1 obtained by Mohammadkhani and Heidari (2008). Distilled water was used as control. Before being tested for germination, seeds were surface-sterilized for five minutes in a $5 \%$ bleach solution and washed three times with distilled water. The working sample consisted of $4 \times 100$ randomly selected seeds. The seeds germinated in Petri dishes double lined with filter paper and moistened with respective solutions, at $20^{\circ} \mathrm{C}$ in a germination chamber (ISTA, 2020). Germination energy was determined after five days, while germination and abnormal seedlings were determined eight days after seed placement in Petri dishes.

Shoot and root lengths were evaluated by allowing 10 pea seeds per cultivar to germinate on premoistened filter paper at the potentials used in the germination test. The rolls were placed in plastic bags and grown at $20^{\circ} \mathrm{C}$ in the germination chamber. Each treatment was carried out in four replications. Shoot and root lengths, as well as fresh shoot and root weights of the 10 seedlings, were determined 8 days following seed placement on filter paper. To obtain the dry weight of seedlings, plants were dried at $80^{\circ} \mathrm{C}$ for $24 \mathrm{~h}$.

\section{Table 1.}

The amount of polyethylene glycol (PEG) 6000 used to achieve different levels of water stress

\begin{tabular}{ccc}
\hline $\begin{array}{c}\text { Osmotic } \\
\text { potential } \\
(\mathrm{MPa})\end{array}$ & $\begin{array}{c}\text { Polyethylene } \\
\text { glycol (PEG) 6000 } \\
\text { (g L-1 of distilled } \\
\text { water) }\end{array}$ & $\begin{array}{c}\text { Polyethylene } \\
\text { glycol (PEG) } \\
6000 \\
\text { concentration } \\
(\%)\end{array}$ \\
\hline Control & 0 & 0 \\
-0.15 & 10 & 10 \\
-0.49 & 20 & 20 \\
-1.03 & 30 & 30 \\
\hline
\end{tabular}

Furthermore, drought tolerance index (DTI) was computed using the formula (Maiti et al., 1994):

$$
\mathrm{DTI}=\mathrm{SDWT} / \mathrm{SDWC}
$$

where SDWT (g) and SDWC (g) are seedling dry weight in treatment and control, respectively.

Statistical analyses were conducted using different software packages. The data were examined by the analysis of variance (one-way ANOVA) using the Statistica 10 (StatSoft, Inc., 2007) software package. The significant differences of means within pea cultivars were separated using Fisher's LSD test $(P<$ 0.05 ) in the GenStat Release 9.1. (Rothamsted Experimental Station) software package.

\section{Results}

The results of the analysis of variance revealed that germination energy, germination, and abnormal seedling percentage were significantly affected by the osmotic potential of polyethylene glycol (PEG) 6000 solution (Table 2). The results obtained for all pea cultivars, as presented in Table 2, show that the decrease in water potential resulted in a significant reduction in germination capacity, although there were significant differences between the studied pea cultivars. Germination energy was significantly reduced by drought stress, compared to control. However, the germination energy of two pea cultivars ( $\mathrm{C} 1$ and C4) was not significantly reduced at an osmotic potential of $-0.15 \mathrm{MPa}$. Nevertheless, this parameter began to decline significantly at an osmotic potential of -0.49 $\mathrm{MPa}$ in all studied pea varieties. Furthermore, under drought stress conditions, minimum values of germination energy were recorded for all varieties under severe stress $(-1.03 \mathrm{MPa})$. At an osmotic potential of $-1.03 \mathrm{MPa}$, the decrease in germination energy ranged between $33.8 \%$ (C4) and $86.9 \%$ (C3) compared to control.

In the control, the germination ranged between $78.00 \%$ (C4) and $92.75 \%$ (C1) (Table 2). In these two cultivars, there was no significant reduction in germination when the osmotic potential was sufficiently low $(-0.15 \mathrm{MPa})$ in comparison with the control. At an osmotic potential of $-0.15 \mathrm{MPa}$, the 
germination percentage of all pea cultivars started decreasing. The decrease in germination ranged between $5.9 \%$ in $\mathrm{C} 1$ and $62.8 \%$ in $\mathrm{C} 3$ compared to control. Moreover, under severe water deficit induced by a high PEG concentration of $30 \%(-1.03 \mathrm{MPa})$, the germination of all the studied pea cultivars decreased significantly compared to control. The largest, almost four-fold decrease in germination percentage was recorded in C3 (22.25\%). The obtained results showed that seed germination was inversely proportional to PEG concentration for C2 and C3.

Table 2.

Effects of different osmotic potentials on germination energy (\%), germination (\%), and abnormal seedlings (\%) of different garden pea cultivars
Pea cultivars
Osmotic potential of PEG (MPa)
Germination energy
(\%)
Germination (\%)
Abnormal seedlings
$(\%)$

\begin{tabular}{|c|c|c|c|c|}
\hline \multirow{5}{*}{$\mathrm{C} 1$} & Control & $89.25 \pm 0.96 a$ & $92.75 \pm 1.26 \mathrm{a}$ & $5.25 \pm 0.50 \mathrm{~b}$ \\
\hline & -0.15 & $90.00 \pm 1.63 \mathrm{a}$ & $90.50 \pm 1.91 \mathrm{ab}$ & $6.00 \pm 1.63 b$ \\
\hline & -0.49 & $86.75 \pm 1.71 b$ & $87.25 \pm 2.22 b$ & $6.00 \pm 1.63 \mathrm{~b}$ \\
\hline & -1.03 & $29.50 \pm 1.73 c$ & $68.50 \pm 3.42 c$ & $9.25 \pm 1.89 \mathrm{a}$ \\
\hline & LSD 0.05 & 2.374 & 3.599 & 2.332 \\
\hline \multirow{5}{*}{$\mathrm{C} 2$} & Control & $31.75 \pm 1.26 \mathrm{a}$ & $78.00 \pm 1.64 \mathrm{a}$ & $9.25 \pm 0.96 \mathrm{~b}$ \\
\hline & -0.15 & $18.75 \pm 1.89 \mathrm{~b}$ & $70.75 \pm 1.26 b$ & $8.00 \pm 2.83 b$ \\
\hline & -0.49 & $10.00 \pm 1.63 c$ & $64.00 \pm 1.64 \mathrm{c}$ & $10.00 \pm 1.64 b$ \\
\hline & -1.03 & $10.00 \pm 1.63 c$ & $45.50 \pm 3.87 \mathrm{~d}$ & $13.75 \pm 2.63 \mathrm{a}$ \\
\hline & LSD 0.05 & 2.49 & 3.606 & 3.313 \\
\hline \multirow{5}{*}{ C3 } & Control & $66.75 \pm 0.96 \mathrm{a}$ & $88.75 \pm 4.11 \mathrm{a}$ & $2.75 \pm 0.96 \mathrm{~d}$ \\
\hline & -0.15 & $42.75 \pm 2.06 \mathrm{~b}$ & $60.00 \pm 2.45 b$ & $4.75 \pm 1.89 c$ \\
\hline & -0.49 & $10.75 \pm 0.96 \mathrm{c}$ & $31.00 \pm 2.83 c$ & $8.00 \pm 1.63 b$ \\
\hline & -1.03 & $8.75 \pm 0.96 \mathrm{c}$ & $22.25 \pm 2.06 \mathrm{~d}$ & $13.50 \pm 2.52 \mathrm{a}$ \\
\hline & LSD 0.05 & 2.038 & 4.568 & 2.83 \\
\hline \multirow{5}{*}{ C4 } & Control & $75.50 \pm 1.00 \mathrm{a}$ & $84.50 \pm 0.58 \mathrm{a}$ & $1.75 \pm 0.96 \mathrm{~b}$ \\
\hline & -0.15 & $77.25 \pm 0.96 a$ & $83.25 \pm 0.50 \mathrm{a}$ & $3.75 \pm 0.96 b$ \\
\hline & -0.49 & $61.25 \pm 0.50 \mathrm{~b}$ & $66.00 \pm 2.83 \mathrm{~b}$ & $4.75 \pm 0.50 \mathrm{~b}$ \\
\hline & -1.03 & $50.00 \pm 3.27 c$ & $53.00 \pm 2.94 \mathrm{c}$ & $6.75 \pm 2.06 \mathrm{a}$ \\
\hline & LSD 0.05 & 2.76 & 3.199 & 1.939 \\
\hline
\end{tabular}

${ }^{*}$ Data are presented as means \pm SD $(n=4)$. Different lowercase letters in the row denote significant differences between means according to Fisher's LSD test at the $P<0.05$ level PEG: Polyethylene glycol (PEG) 6000

The percentages of abnormal seedlings in the studied pea cultivars, as affected by different osmotic potentials, are presented in Table 2 . In the absence of stress, small values of abnormal shoots were recorded in most of the cultivars, except C2 (9.25\%). No significant differences in the percentage of abnormal seedlings occurred in $\mathrm{C} 1, \mathrm{C} 2$, and $\mathrm{C} 4$ at -0.15 and -0.49 $\mathrm{MPa}$. However, C2 (13.75 \%) and C3 (13.50\%) exhibited the highest percentage of abnormal seedlings under severe stress (-1.03 $\mathrm{MPa})$.

Water deficit induced by polyethylene glycol (PEG) 6000 also affected seedling development. Results of shoot and root length (Table 3 ) showed that the highest values for all the tested cultivars were recorded at zero potential (control). However, pea cultivars reacted differently to the drought levels in these parameters. Drought stress induced by PEG led to a decrease in shoot and root length in all pea cultivars in comparison to control. At the osmotic potentials of - $0.15 \mathrm{MPa}$ and -
0.49 $\mathrm{MPa}$, no significant differences were observed in terms of shoot and root length in $\mathrm{C} 1$ and $\mathrm{C} 2$, while all the tested treatments gradually reduced the shoot and root length of C3 and C4 in comparison to control.

Fresh shoot and root weights of the studied pea cultivars, as affected by different levels of drought stress, are presented in Table 3 . The highest values of fresh shoot biomass were determined in the absence of stress and ranged between $0.751 \mathrm{~g} \mathrm{(C3)} \mathrm{and} 0.919 \mathrm{~g}$ (C2). The fresh shoot weight of the three pea cultivars (C2, C3, and C4) was inversely proportional to the PEG concentration. At an osmotic potential of $-1.03 \mathrm{MPa}$, the fresh shoot weight of pea cultivar C2 was decreased 4.7-fold in comparison to control. Nevertheless, the fresh shoot weight of pea cultivar C1 was affected by drought to a lesser extent. However, a significant decrease in shoot weight was observed only when the osmotic potential reached -1.03 MPa. Furthermore, the fresh root weight of the studied pea cultivars ranged 
between $0.875 \mathrm{~g}$ (C3) and $1.486 \mathrm{~g}$ (C2) in control. Likewise, the highest fresh root weight was observed in the absence of drought stress in C2, C3, and C4, and had a similar downward trend following the decrease in the osmotic potential. Interestingly, the highest fresh root weight, observed in C1 (1.335 g), was at $-0.15 \mathrm{MPa}$. Furthermore, a significant reduction in the fresh root weight of $\mathrm{C} 1$ occurred only under severe stress, when the osmotic potential reached $-1.03 \mathrm{MPa}$.

Table 3.

Effects of different osmotic potentials on shoot and root length ( $\mathrm{mm}$ ) and fresh biomass accumulation (g) in different garden pea cultivars

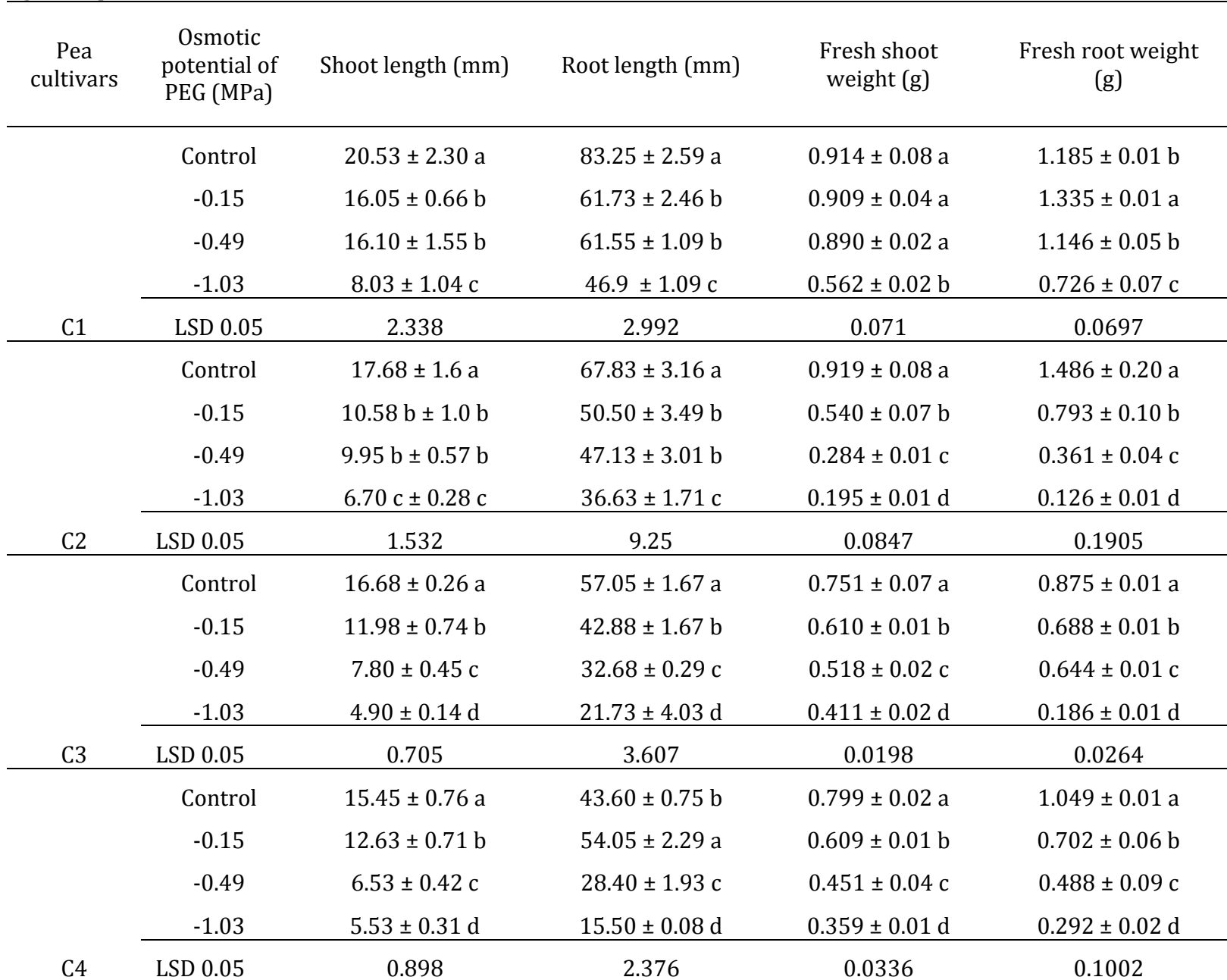

$*$ Data are presented as means \pm SD $(n=4)$. Different lowercase letters in the row denote significant differences between means according to Fisher's LSD test at the $P<0.05$ level PEG: Polyethylene glycol (PEG) 6000

Dry shoot and root biomass was severely reduced in the presence of polyethylene glycol (PEG) 6000 (Table 4). Similarly, the highest values of dry shoot weight were observed in the absence of water deficit (control). All treatments gradually reduced dry shoot weight in C2, C3, and C4. The lowest dry shoot weight was observed in C2 $(0.0184 \mathrm{~g})$ under severe stress ($1.03 \mathrm{MPa}$ ). In contrast, a significant reduction in dry root biomass in $\mathrm{C} 1$ occurred only at an osmotic potential of $-1.03 \mathrm{MPa}$. In addition, dry root biomass generally decreased following an increase in drought stress in all studied pea cultivars.
The obtained results revealed that drought tolerance index varied among pea cultivars in the presence of drought stress (Table 4). Drought tolerance index gradually decreased in $\mathrm{C} 2, \mathrm{C} 3$, and C4 after the application of increased PEG concentrations. Under a severe water deficit (-1.03 MPa), the DTI of these pea cultivars decreased between $47.9 \%$ and $85.7 \%$ in comparison to control. The smallest DTI was observed in C2 (0.153) as the most sensitive variety. However, pea cultivar C1 proved to be the most tolerant to drought, given that its DTI significantly decreased only at an osmotic potential of $-1.03 \mathrm{MPa}$ (DTI 0.613) compared to control. 
Table 4.

Effects of different osmotic potentials on dry biomass accumulation $(\mathrm{g})$ and drought tolerance index in different garden pea cultivars

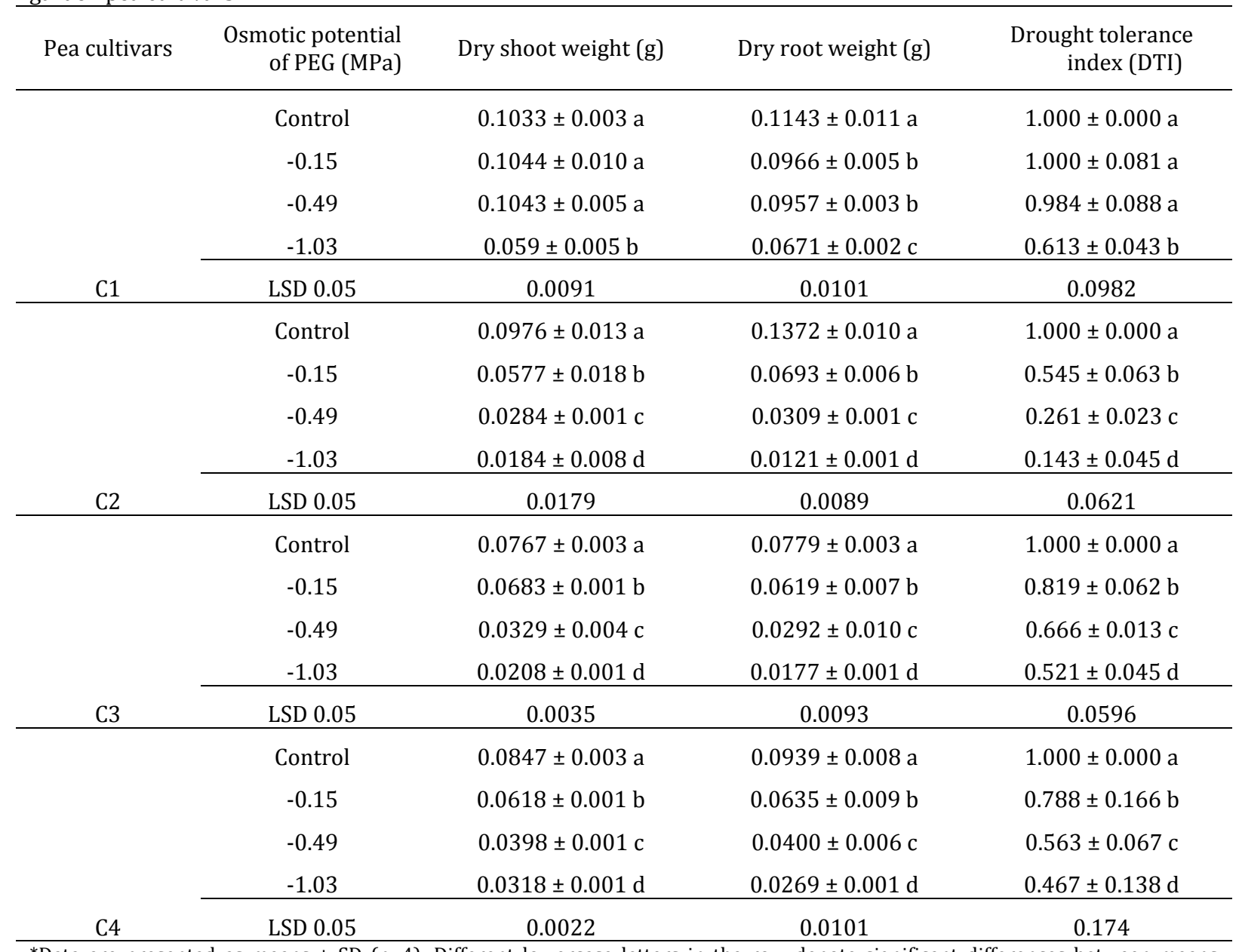

*Data are presented as means \pm SD $(n=4)$. Different lowercase letters in the row denote significant differences between means according to Fisher's LSD test at the $P<0.05$ level PEG: Polyethylene glycol (PEG) 6000

\section{Discussions}

The present study aimed to examine the effects of different osmotic potentials of polyethylene glycol (PEG) 6000 solution on physiological seed quality and initial seedling growth stage in four pea cultivars grown under controlled conditions. Most researchers used polyethylene glycol (PEG) 6000 as a strong water stress simulator for the establishment of a water deficient environment under laboratory conditions (Saima et al., 2018). A positive correlation was observed between the drought tolerance of the genotypes grown in the field and the laboratory experiments (Kosturkova et al., 2014).

Crop production mainly depends on seed germination and initial seedling growth under stress conditions such as drought. The obtained results of the study showed that increasing drought stress reduced the germination capacity of the pea cultivars. A reduction in the germination energy and germination percentage of pea cultivars was observed when osmotic potential reached $-0.49 \mathrm{MPa}$. Similar results were reported by Pereira et al. (2020) in pea, Pereira et al. (2014) in Raphanus raphanistrum L. and Senna obtusifolia L., Radić et al. (2018) and Mohammadkhi and Heidari (2008) in maize, Rana et al. (2017) in wheat, Basal et al. (2020) in soybean, etc. This reduction in germination capacity might be attributed to the lower infusibility of water through the seed coat and water uptake by seeds under drought stress (Bahrami et al., 2014; Channaoui et al., 2019). Pereira et al. (2020) stated two possible reasons for the reduction in germination under a more negative osmotic potential. The first possible reason for the reduction in germination percentage under osmotic stress is the increase in time length corresponding to phase III of the imbibition process, while the second reason is the high molecular weight of polyethylene glycol (PEG) 6000, which is not absorbed due to high viscosity. As suggested by Braccini et al. (1996), these facts, together with the correspondingly low 02 diffusion rate, can compromise the supply of oxygen to the seeds during the germination process. Furthermore, degradation and inactivation of hydrolytic and other groups of enzymes required for germination might be the result of severe drought stress (Pratab and Sharma, 2010; Rana et al., 2017). Also, a significant increase in abnormal seedling percentage under severe drought stress was observed for all studied cultivars in this study. These results are in agreement with Badr et al. (2020), who found that the primary action of moisture deficit imposed by drought is impaired germination. Similar results were obtained in the studies on lentil (Foti et al., 2018). 
Pea seedlings subjected to the different osmotic potentials of polyethylene glycol solution showed significant differences in shoot and root length. There were no significant differences for root and shoot growth at osmotic potentials of $-0.15 \mathrm{MPa}$ and -0.49 MPa (moderate drought) in the pea cultivars C1 and C2. For C3 and C4, the results showed that seedling length was inversely proportional to the PEG concentration. The reduction in initial plant growth due to water deficit was also observed in maize (Badr et al., 2020), pea (Pereira et al., 2020), rapeseed (Channaoui et al., 2019), mung bean (Saima et al., 2018), and other crops. The reduction in seedling length was due to changes in cell turgidity caused by a reduction in protein synthesis under drought conditions (Pereira et al., 2020). Drought stress caused restricted cell division and enlargement, which led to a reduction in seedling growth (Badr et al., 2020). Differences in the response of pea cultivars to drought conditions regarding seedling length can be explained by the fact that vigorous seeds give rise to seedlings with a higher growth rate due to their greater capacity for transforming supplies from storage tissue reserves and their incorporation by the embryonic axis (Nascimento et al., 2017; Pereira et al., 2020).

Fresh and dry shoot and root weights were affected by drought stress imposed by PEG, but the shoots were affected to a lesser extent than roots. Our findings showed that fresh shoot and root weights were depressed by lowering the osmotic potential. Moreover, distinctive genetic differences concerning these parameters were found between the pea cultivars. Under severe water deficit, fresh shoot weight decreased almost 5-fold compared to control. However, the findings underline the superior performance of $\mathrm{C} 1$ in terms of the studied parameters. Interestingly, the fresh shoot weight of $\mathrm{C} 1$ was increased at $-0.15 \mathrm{MPa}$ while it was decreased only at $1.03 \mathrm{MPa}$. This is in agreement with the earlier studies on tomato genotypes conducted by Shahim et al. (2014), who determined that seeds tolerant of drought stress produce a stronger root system. Several studies agree with the current results, stating that under the conditions of drought stress, biomass accumulation in higher plants is reduced (Mohammadkhi and Heidri, 2008; Shahim et al., 2014; Saima et al., 2018). Similar to the results of fresh biomass accumulation, our findings once again confirmed that C1 was less susceptible to drought stress since dry shoot weight was significantly reduced only at an osmotic potential of $-1.03 \mathrm{MPa}$, while dry root weight was slightly decreased at -0.15 $\mathrm{MPa}$ and $-0.49 \mathrm{MPa}$, and significantly decreased under severe drought stress (-1.03 MPa). For the other studied pea cultivars, all the tested treatments gradually reduced dry seedling biomass in comparison to control. These results are in agreement with the findings of Pereira et al. (2020), who related the reduction in dry biomass to the reduction in seed metabolism due to the lower availability of water. Nascimento et al. (2017) also reported a reduction in the dry shoot and root biomass of Phaseolus lunatus under drought stress. In contrast, Piwowarczyk et al. (2014) recorded higher accumulation of dry biomass in Lathyrus species under PEG-induced osmotic stress. According to Soni et al. (2011), it might be associated with the dehydration process and synthesis of new material required to maintain a higher osmoticum to continue water absorption.
An important aim of this study was to classify the studied garden pea cultivars based on their response to drought stress. The pea cultivar C1 was singled out as drought-tolerant, given the fact that it had the highest drought tolerance index (DTI). This pea cultivar had the best performance estimated as the maximum germination percentage, shoot and root length, and fresh and dry seedling biomass under severe drought stress. The other pea cultivars were classified as drought-susceptible based on the drought tolerance index. In this regard, Krishnamurthy et al. (2007) suggested that reduced drought tolerance index in susceptible genotypes might be due to the PEG induced osmotic effect, which was deleterious and changed plants to maintain the nutritional content necessary for their healthy growth.

\section{Conclusions}

Germination and seedling development were evaluated in the laboratory under induced stress simulated by polyethylene glycol (PEG) 6000 so as to assess the drought tolerance of the selected pea cultivars. Based on the obtained results, the studied pea cultivars differed in their response to drought stress, which coincided with seed germination capacity and initial seedling growth and development. At an osmotic potential of $-0.49 \mathrm{MPa}$, all of the observed parameters significantly declined in more susceptible pea cultivars. Therefore, the osmotic potential of the solution might be the germination sensitivity threshold for pea cultivars. In conclusion, due to its better values of germination, seedling growth, biomass accumulation, and drought tolerance index under severe drought conditions, C1 stands out as the most tolerant pea cultivar. This pea cultivar might be used as the tolerant control in future studies. However, further research is required for the assessment of physiological and biochemical responses to drought stress, such as chlorophyll content, stomatal conductance, and ROS production.

\section{Acknowledgment}

This research was supported by the Ministry of Education, Science and Technological Development of the Republic of Serbia, grant number: 451-03-9/202114/ 200032. The authors warmly thank the Center of Excellence for Legumes of the Institute of Field and Vegetable Crops, who assisted in this research.

\section{Declaration of competing interest}

The authors declare that they have no known competing financial interests or personal relationships that could have appeared to influence the work reported in this paper.

\section{References}

Badr, A., El-Shazly, H. H., Tarawneh, R. A., Börner, A. (2020). Screening for drought tolerance in maize (Zea mays L.) germplasm using germination and seedling traits under simulated drought conditions. Plants, 9, 565.

Bahrami, H., Razmjoo, J., Ostadi Jafari, A. (2014). Effect of drought stress on germination and seedlings growth of sesame cultivars (Sesamum indicum L.). International Journal of Agricultural Science, 2(5), 423-428. 
Basal, O., Szabo, A., Veres, S. (2020). Physiology of soybean as affected by PEG-induced drought stress. Current Plant Biology, 22, 100135.

Braccini, A. L., Ruiz, H. A., Braccini, M. C. L., Reis, M. S. (1996). Germinaçáo e vigor de sementes de soja sob estresse hidrico induzido por soluções de cloreto de sódio, mannitol e polietilenglicol. Revista Brasiliera de Sementes, $18,10-16$.

Channaoui, S., Idrissi, I. S., Mazouz, H., Nabloussi, A. (2019). Reaction of some rapeseed (Brassica napus L.) genotypes to different drought stress levels during germination and seedling growth stages. Oilseeds and fats, Crops and Lipids, 26(23), 1-10.

Fougereux, J. A., Doré, T., Ladonne, F., Fleury, A. (1997). Water stress during reproductive stages affects seed quality and yield of pea (Pisum sativum L). Crop Science, 37(4), 12471252.

Foti, C., Khah, E., Pavli, O. (2018). Response of lentil genotypes under PEG-induced drought stress: Effect on germination and growth. Plant, 6(4), 75-83.

ISTA (2020). International Rules for Seed Testing. Seed Science and Technology. Zurich, Switzerland.

Jovićević, D. (2011). Proizvodnja graška. U: Milošević, M., Kobiljski B. (eds.): Semenarstvo III. Institut za ratarstvo i povrtarstvo, Novi Sad, pp. 291-340.

Kosturkova, G., Todorova, R., Dimitrovai, M., Tasheva, K. (2014). Establishment of Test for Facilitating Screening of Drought Tolerance in Soybean. Scientific Bulletin. Series F. Biotechnologies, 18, 32-37.

Krishnamurthy, L., Serraj, R., Hash, C.T., Dakheel, A.J., Reddy, B.V. (2007). Screening sorghum genotypes for salinity tolerant biomass production. Euphytica, 156(1-2), 15-24.

Maiti, R.K., De La Rosa-Ibarra, M., Sandoval, N.D. (1994). Genotypic Variability in Glossy Sorghum Lines for Resistance to Drought, Salinity and Temperature Stress at the Seedling Stage. Journal of Plant Physiology, 143, 241 244.

Miladinov, Z., Maksimović, I., Balešević Tubić, S., Đukić, V., Nikolić, Z., Milošević, B., Katanski, S. (2020). Priming seeds-method for increasing the germination of soybean seeds under drought stress conditions. Acta Agriculturae Serbica, 25(50), 105-111.

Mohammadkhari, N., Heidri R. (2008). Water stress induced by polyethylene glycol 6000 and sodium chloride in two maize cultivars. Pakistan Journal of Biological Sciences, 11(1), 92-97.

Nascimento, M. G. R., Alves, E. U., Silva, M. L. M., Rodrigues, C. M. (2017). Lima bean (Phaseolus lunatus L.) seeds exposed to different salt concentrations and temperatures. Revista Catinga, 30, 738-747.

Nicholas, P.M. (1989). Osmotic pressure of aqueous polyethylene glycols. Plant Physiology, 91, 766-769.
Pereira, I. C., Catão, H. C. R. M., Caixteta, F. (2020). Seed physiological quality and seedling growth of pea under water and salt stress. Revista Brasileira de Engenharia Agricola e Ambiental, 24(2), 95-100.

Pereira, M.R.R., Martins, C.C., Martins, D., Silva, R.J.N. (2014). Saline water stress and the germination of seeds of Raphanus raphanistrum and Senna obtusifolia. Bioscience Journal, 30(3), 687-696.

Petrović, G., Jovičić, D., Nikolić, Z., Tamindžić, G., Ignjatov, M., Milošević, D., Milošević, B. (2016). Comparative study of drought and salt stress effects on germination and seedling growth of pea. Genetika, 48(1), 373-381.

Piwowarczyk, B., Kamińska, I., Ryniński, W. (2014). Influence of PEG generated osmotic stress on shoot regeneration and some biochemical parameters in Lathyrus culture. Czech Journal of Genetics and Plant Breeding, 50(2), 7783.

Pratab, V., Sharma, Y. K. (2010). Impact of osmotic stress on seed germination and seedling growth in black gram (Phaseolus mungo). Journal of Environmental Biology, 31(5), 721-726.

Radić, V., Balalić, I., Cvejić, S., Jocić, S., Marjanović-Jeromela, A., Miladinović, D. (2018). Drought effects on maize seedling development. Ratarstvo i povrtarstvo, 55(3), 135-138.

Rana, M. S., Hasan, M. A., Bahadur, M. M., Islam, M. R. (2017). Effect of polyethylene glycol induced water stress on germination and seedling growth of wheat (Triticum aestivum). The Agriculturists, 15(1), 81-91.

Saima, S., Li, G., Wu, G. (2018). Effects of drought stress on hybrids of Vigna Radiata at germination stage. Acta Biologica Hungarica, 69(4), 481-492.

Shahim, F., Saqlan, S. M., Athar, H. R., Waheed, A. (2014). Screening and selection of tomato genotypes/cultivars for drought tolerance using multivariate analysis. Pakistan Journal of Botany, 46, 1165-1178.

Soni, P., Rizwan, M., Bhatt, K. V., Mohapatra, T., Singh, G. (2011). In-vitro response of Vigna aconitifolia to drought stress induced by PEG - 6000. Journal of Stress Physiology and Biochemistry, 7, 108-121.

Versules, P. E., Bray, E. A. (2004). LWR1 and LWR2 are required for osmoregulation and osmotic adjustment in Arabidopsis. Plant Physiology, 136, 2831-2842.

Vijay, R., Ravichandran, V., Boominathan, P. (2018). Assessment of soybean genotypes for PEG induced drought tolerance at germination and seedling level. Madras Agricultural Journal, 105(1-3), 1-6.

Wu, C., Wang, Q., Xie, B., Wang, Z., Cui, J., Hu, T. (2011). Effects of drought and salt stress on seed germination of three leguminous species. African Journal of Biotechnology, 10(78), 17954-17961. 